\title{
Easternmost record of the Cuban Broad-banded Trope, Tropidophis feicki (Squamata: Tropidophiidae)
}

\author{
Tomás M. Rodríguez-Cabrera ${ }^{1 *} \mathbb{D}$, Javier Torres $^{2} \mathbb{D}$, and Ernesto Morell Savall ${ }^{3}$ \\ 'Sociedad Cubana de Zoología, Cuba. \\ ${ }^{2}$ Department of Ecology and Evolutionary Biology, University of Kansas, Lawrence, Kansas 66045, USA. \\ ${ }^{3}$ Área Protegida "Sabanas de Santa Clara," Empresa Nacional para la Protección de la Flora y la Fauna, Villa Clara 50100, Cuba. \\ *Corresponding author (tomasmichel.rodriguez@gmail.com)
}

Edited by: Robert W. Henderson. Date of publication: 14 May 2020.

Citation: Rodríguez-Cabrera TM, Torres J, Morell Savall E (2020) Easternmost record of the Cuban Broad-banded Trope, Tropidophis feicki (Squamata: Tropidophiidae), of Cuba. Caribbean Herpetology, 71, 1-3.

DOI: https://doi.org/10.31611/ch.71

Tropidophis feicki Schwartz, 1957 is restricted to densely forested limestone mesic areas in western Cuba (Schwartz \& Henderson 1991; Henderson \& Powell 2009). This species has been reported from about 20 localities distributed from near Guane, in Pinar del Río Province, to Ciénaga de Zapata, in Matanzas Province Rivalta et al., 2013; GBIF 2020; Fig. 1).

On 30 June 2009 and on 22 December 2011 we found an adult male and an adult female Tropidophis feicki (ca. $400 \mathrm{~mm}$ SVL; Fig. 2), respectively, at the entrance of the "Cueva de la Virgen" hot cave (22.8201, -80.1384; $30 \mathrm{~m}$ a.s.l.; WGS 84; point 14 in Fig. 1). The cave is located within "Mogotes de Jumagua" Ecological Reserve, Sagua La Grande Municipality, Villa Clara Province. This locality represents the first record of this species for central Cuba, particularly for Villa Clara Province. This new record is about $123 \mathrm{~km}$ northeast (airline distance) of the nearest previous record at Playa Máquina, Ciénaga de Zapata, Matanzas Province (Rodríguez \& Rivalta 2007).

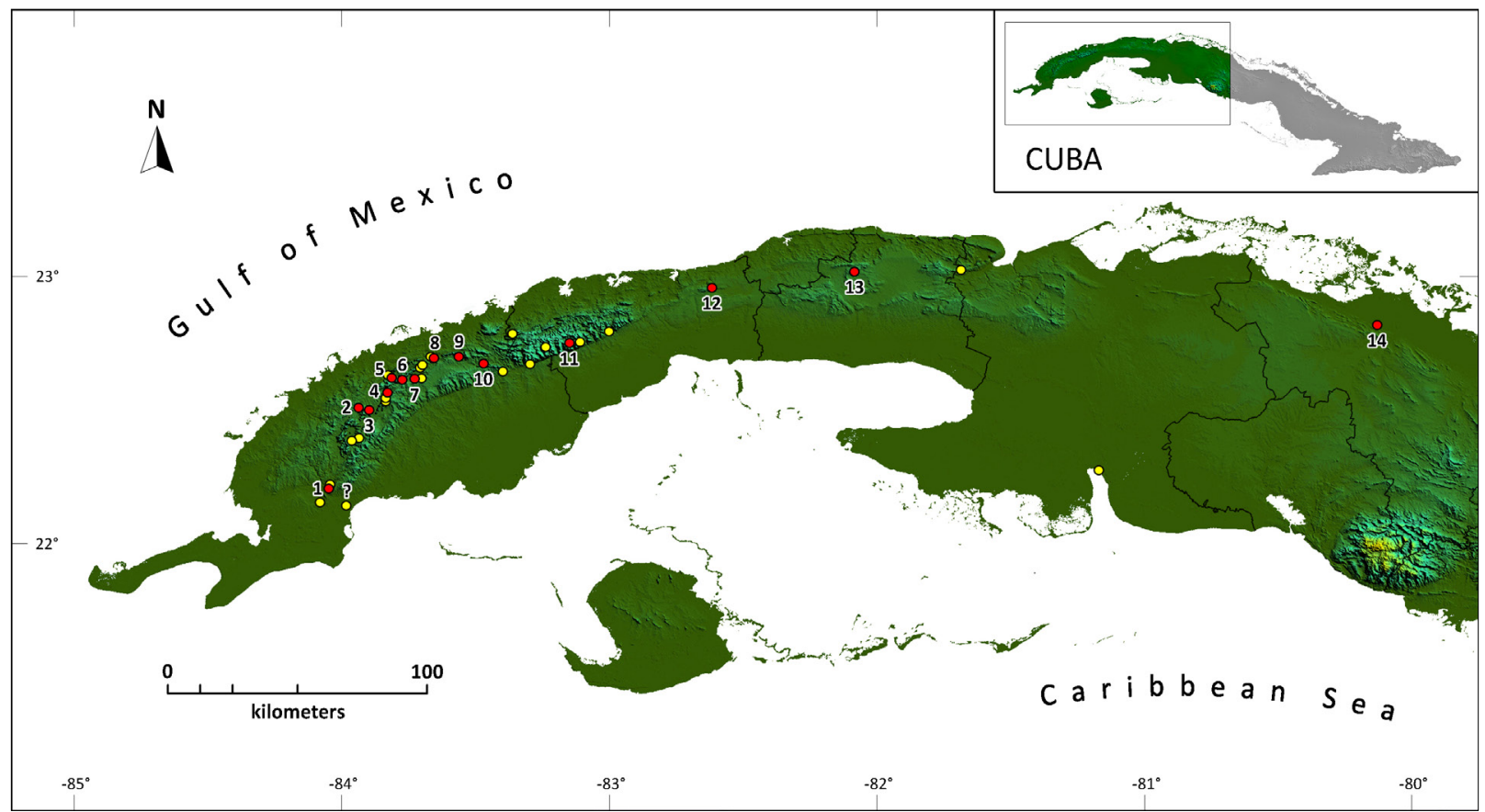

Figure 1. Map of western and central Cuba depicting the distribution of Tropidophis feicki, including records from the literature (yellow dots) and this paper (red dots). Numbered localities are in the text. The question mark (?) represents a published record that needs confirmation (i.e., "San Ubaldo-Sabanalamar" Flora Reserve; Rodríguez et al. 2013). 
Other new locality records for T. feicki are indicated by numbers in Figure 1. PINAR DEL RíO Province. Guane Municipality: (1) Sierra de Guane (22.2025, -84.0561); Minas de Matahambre Municipality: (2) Sierra La Mar (22.5070, -83.9446); and (3) Sierra Gramales (22.4991, -83.9030). Viñales Municipality: (4) Maravillas de Viñales trail (22.5631, -83.8336); (5) SE of Pan de Azúcar (22.6177, -83.8231); (6) Sierra del Infierno (22.6152, -83.7770); (7) Mogote del Valle (22.6148, -83.7341); and (8) Mogote La Mina (22.6969, -83.6628). La Palma Municipality: (9) Sierra Guacamaya (22.6964, -83.5739); and (10) Cueva Los Portales (22.6689, -83.4790). ARTEMISA Province. San Cristóbal Municipality: (11) Río Santa Cruz (22.7495, -83.1498). Caimito Municipality: (12) Sierra Esperón (22.9566, -82.6243). MAYABEQUE Province: border between Jaruco and San José de las Lajas municipalities: (13) entrance of Cueva del Indio (23.0183, -82.0896).

Records of Tropidophis feicki outside the Guaniguanico mountain range are scarce and isolated (Fig. 1). Intermediate records between this mountain range and Matanzas Province have been mapped in previous works without details (Schwartz \& Henderson 1991; Tolson \& Henderson 1993). These records were overlooked in later contributions (Rodríguez et al. 2013). Nonetheless, our records from Sierra Esperón and Cueva del Indio corroborate the occurrence of the species in this intermediate area.

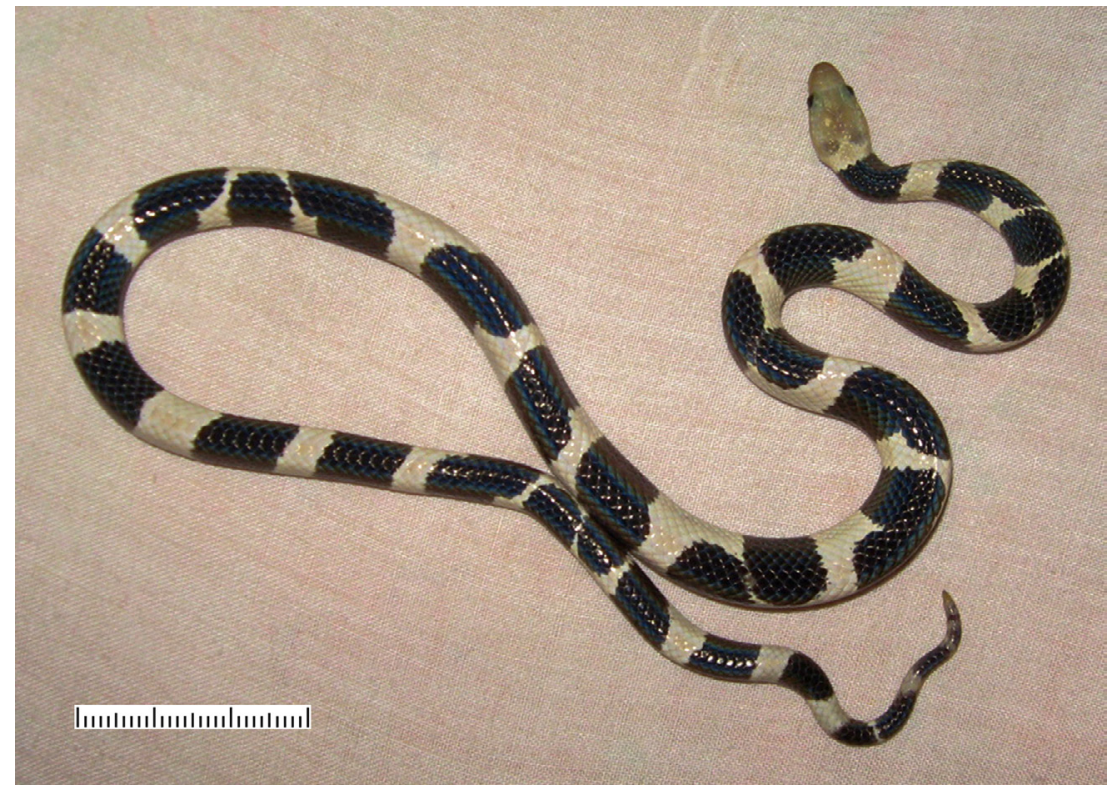

Figure 2. Adult female Tropidophis feicki from "Mogotes de Jumagua" Ecological Reserve, Villa Clara Province, the easternmost record of the species. Scale bar in millimeters. Photo by E. Morell Savall.

We also report natural history observations from individuals outside of the Guaniguanico mountain range. We found Tropidophis feicki from "Mogotes de Jumagua" Ecological Reserve about two hours after sunset foraging on limestone cliffs between 1.5 and $2 \mathrm{~m}$ above the ground, which is consistent with previous observations (Schwartz 1957; Schwartz \& Henderson 1991). We kept them in captivity for several months and noted that they were permanently as pale as other individuals from western populations during the pale phase at night (Rehák 1987; Hedges et al. 1989). We observed the same pattern in two individuals from Sierra Esperón, in which the ground color was also permanently pale yellowish instead of whitish (pale phase) or grayish brown (dark phase). The snakes from Ciénaga de Zapata exhibited an unusual pinkish ground coloration (O.H. Garrido pers. comm.).

\section{Acknowledgments}

We thank L. Yusnaviel García, Elier Fonseca, and Orlando H. Garrido for sharing unpublished data. We also thank the administration and staff of "Mogotes de Jumagua" Ecological Reserve and Tomás García and family (Santa Cruz river) for logistical support and accommodations. 


\section{References}

GBIF (2020) Global Biodiversity Information Facility. Available from http://www.gbif.org/ (accessed 23 April 2020). Copenhagen, Denmark: Global Biodiversity Information Facility.

Hedges SB, Hass CA, Maugel TK (1989) Physiological color change in snakes. Journal of Herpetology, 23, 450-455.

Henderson RW, Powell R (2009) Natural History of West Indian Amphibians and Reptiles (University of Florida Press, Gainesville, Florida).

Rehák I (1987) Color change in the snake Tropidophis feicki (Reptilia: Squamata:Tropidophiidae). Véstník Ceskoslovenské Spolecnosti Zoologické, 51, 300-303.

Rivalta González V, González-C. A, Rodríguez-S.[chettino] (2013) Colección herpetológica del Instituto de Ecología y Sistemática, La Habana, Cuba. Familia Tropidophiidae, género Tropidophis. Revista Colombiana de Ciencia Animal, 5, 282-300.

Rodríguez-Schettino L, Rivalta[González] V (2007) Efectos probables del aumento del nivel del mar sobre la herpetofauna de la Reserva de la Biosfera Ciénaga de Zapata, Matanzas, Cuba. Poeyana, 495, 8-13.

Rodríguez-Schettino L, Mancina CA, Rivalta González V (2013) Reptiles of Cuba: Checklist and geographic distribution. Smithsonian Herpetological Information Service, 144, 1-96.

Schwartz A (1957) A new species of boa (genus Tropidophis) from western Cuba. American Museum Novitates, 1839, $1-8$.

Schwartz A, Henderson RW (1991) Amphibians and Reptiles of the West Indies. Descriptions, Distributions, and Natural History (University of Florida Press, Gainesville).

Tolson PJ, Henderson RW (1993) The Natural History of West Indian Boas (R \& A Publishing Limited, Somerset). 